\title{
Changes in Sperm Morphology and Characteristics of Experimentally-induced Hypertensive Wistar Rats Treated with Lagenaria breviflora Roberty or Xanthosoma sagittifolium Exell
}

\author{
Olayinka A. Oridupa $^{1^{*}}$, Oluwasanmi O. Aina ${ }^{2}$, Temitope S. Lawal ${ }^{1}$ \\ and Adebowale B. Saba ${ }^{1}$ \\ ${ }^{1}$ Department of Veterinary Pharmacology and Toxicology, University of Ibadan, Ibadan, Nigeria. \\ ${ }^{2}$ Department of Veterinary Anatomy, University of Ibadan, Ibadan, Nigeria.
}

\section{Authors' contributions}

This work was carried out in collaboration among all authors. Author OAO designed the study, wrote the protocol and wrote the first draft of the manuscript. Author OOA carried out the study and statistical analyses. Author TSL managed the animal study and managed the literature searches.

Author ABS designed the study and wrote the final draft of the manuscript. All authors read and approved the final manuscript.

Article Information

DOI: 10.9734/ARRB/2018/v30i630030

Editor(s):

(1) Dr. Md. Torequl Islam, Nuclear of Pharmaceutical Technology (NTF), Postgraduate Program in Pharmaceutical Sciences, Federal University of Piaui, Brazil.

(2) Dr. George Perry, Dean and Professor of Biology, University of Texas at San Antonio, USA. Reviewers: (1) Heba Atia Yassa, Assiut University, Egypt. (2) Igor Iskusnykh, University of Tennessee Health Science Center, USA. Complete Peer review History: http://www.sdiarticle3.com/review-history/47027

Original Research Article

Received 25 November 2018

Accepted 03 February 2019

Published 15 March 2019

\section{ABSTRACT}

Aims: This study was designed to evaluate the male reproductive toxicity that may accompany treatment of hypertension in Wistar rats with methanol extracts of whole fruit of Lagenaria breviflora Roberty or corm of Xanthosoma sagittifolium Schott.

Place and Duration of Study: The study was carried out at the Animal House of the Department of Veterinary Pharmacology and Toxicology between November, 2016 and January, 2017.

Methodology: Antihypertensive study was carried out in 40 adult male Wistar rats equally and randomly distributed into 8 groups. First group was normotensive rats administered with distilled water, while hypertension was induced in groups 2-7 intraperitoneal administration of DOCA-salt 
twice weekly and daily inclusion of $1 \%$ sodium chloride in drinking water. Group 2 was hypertensive but untreated rats. Two hypertensive groups were administered with Lisinopril (5 mg/70 kg) or Hydrochlorothiazide $(12.5 \mathrm{mg} / 70 \mathrm{~kg}$ ). Two hypertensive groups were assigned to each extract and these rats were administered with the extracts at doses of 100 or $200 \mathrm{mg} / \mathrm{kg}$ body weight. The rats were treated per os for 5 weeks and sacrificed at the end of this period. The testes were harvested and semen samples were obtained from the left cauda epididymis. Semen analysis were carried out to determine sperm morphology and characteristics.

Results: Result showed 1 primary and 7 secondary sperm abnormality types were observed with a non-significant $(p>0.05)$ increase in total abnormal sperm cells. Live/dead ratio and sperm volume were unchanged but, sperm motility and count were significantly $(p<0.05)$ reduced.

Conclusion: It was inferred from the study that hypertension in itself induced infertility and also treatment of the medical condition with the extracts of $L$. breviflora or $X$. sagittifolium did not reverse the infertility. Therefore, caution should be exercised when treating hypertension with these medicinal plants, particularly in male animals used for breeding.

Keywords: Lagenaria breviflora Roberty; Xanthosoma sagittifolium Schott; antihypertensive; andrology.

\section{INTRODUCTION}

Infertility in the male is the inability to produce fertile sperm cells or semen for fertilization of fertile ovum, which does not lead to conception of the female bred [1]. Male infertility may be induced by many factors which include diseases, exposure to environmental conditions, adverse drug effect or plants [2]. One lifelong noninfectious disease with infertility as one of its sequels is hypertension. Several studies examining hypertensive men demonstrated a significant inverse relationship between blood pressure and total serum testosterone, which could be associated with impaired reproductive potential, free testosterone and sex hormonebinding globulin $[3,4,5,6]$.

Clinically, various classes of antihypertensive drugs such as Angiotensin Converting Enzymes Inhibitors, calcium channel blockers, loop diuretic have been used to manage hypertension and to alleviate symptoms $[7,8]$. However, the efficacy of these drugs is only $40-60 \%$ usually with a combination of two or more antihypertensive drugs from different categories and this invariably increases the cost of treatment and accompanying side effects [9]. Frequently observed adverse effects of synthetic antihypertensive drugs include emotional distress, gastrointestinal disturbance, dry mouth, dizziness, cough, visual disorders, headache, peripheral circulatory symptoms like cold hands and feet, pedal oedema $[10,11]$.

Herbal medicines have been commonly used as alternative therapies and remain so instead of synthetic drugs because of their possible fewer side effects [12]. Medicinal plants reported to be used in the treatment of hypertension include Colocasia esculenta [13], Guiera senegalensis leaves [14]. The focus of this study was on the possible adverse effects that may accompany treatment of hypertension with Lagenaria breviflora whole fruit or Xanthosoma sagittifolium corm, with particular emphasis on the reproductive toxicity in experimentally-induced hypertensive male Wistar rats. These medicinal plants have been traditionally recommended to hypertensive patients with some unverified result.

L. breviflora (family Cucurbitaceae) is locally used for treatment of diseases of inflammatory origin and known to possess potent antioxidant, anti-inflammatory and analgesic properties $[15,16,17]$. It is reported to lower fertility in normal Wistar rats [18]. $X$. sagittifolium (family Araceae) is a very close relative of $C$. esculenta which is widely used as a replacement source of carbohydrate for diabetics [19]. It has potent antioxidant property as well [20], but there is a sparsity of information on its effect on the male reproductive system. Male reproductive toxicity will be assessed by the changes in the spermatozoa morphology and characteristics.

\section{MATERIALS AND METHODS}

\subsection{Plant Material and Preparation of Extracts}

Fresh fruits of Lagenaria breviflora Roberts and corms of Xanthosoma sagittifolium were purchased from Bodija Market, Ibadan, Nigeria in July 2015 and identified by botanists at the Department of Botany, University of Ibadan. $L$. 
breviflora fruits were washed, cut into pieces, weighed and dried using a hot air oven set at $25^{\circ} \mathrm{C}$ for 72 hours. The tubers of $X$. sagittifolium was peeled, cut into pieces and air dried for one week. The dried plant materials were then soaked in methanol for 96 hours for extraction as described by Oridupa and Saba [17]. The extract was then filtered and concentrated using a rotary evaporator (BUCHI R-210, Switzerland). The remaining methanol was removed by placing small volumes on a crucible and evaporated over water bath set at $30^{\circ} \mathrm{C}$.

Methanol (96\% Purity), 11-Deoxycorticosterone (DOC) Salt (98\% Purity), Sodium chloride (99.5\% Purity), Nigrosin and Eosin stains were purchased from Sigma Aldrich (Germany). Lisiniprol was purchased from AstraZeneca Pharmaceuticals (United Kingdom), while Hydrochlorothiazide was purchased from Polpharma (Poland).

\subsection{Experimental Animals}

Forty normotensive male Wistar rats (150 - 200g) were used for the study. The rats were housed at the Experimental Animal House of the Department of Veterinary Pharmacology \& Toxicology, University of Ibadan. They were allowed access to feed (commercially available rat pellets) and water ad libitum. The animals were humanely handled in accordance with the guidelines for the Animal Care and Use Regulation Ethical Committee of the University of Ibadan, Ibadan, Nigeria.

\subsection{Experimental Procedure}

The animals were randomly and equally divided into eight groups with 5 rats each. Rats in Group 1 were maintained as control normotensive, while hypertension was induced and maintained in groups 2-8 by intraperitoneal injection of 11Deoxycorticosterone (DOC) Salt $(25 \mathrm{mg} / \mathrm{kg}$ ) twice weekly and daily inclusion of $2 \%$ sodium chloride in drinking water. The blood pressure of the rats was determined before commencement of treatment.

Group 1 was normotensive rats fed with commercial rat pellet and allowed access to clean water ad libitum. Group 2 were hypertensive untreated rats, groups 3 and 4 were hypertensive rats treated with Lisinopril $5 \mathrm{mg} /$ $70 \mathrm{~kg}$ or Hydrochlorothiazide $12.5 \mathrm{mg} / 70 \mathrm{~kg}$ body weight. Groups 5 and 6 were also hypertensive rats treated with $L$. breviflora Roberty methanol extract at $100 \mathrm{mg} / \mathrm{kg}$ or $200 \mathrm{mg} / \mathrm{kg}$ body weight, while groups 7 and 8 were treated with $X$. sagittifolium methanol extract at $100 \mathrm{mg} / \mathrm{kg}$ or $200 \mathrm{mg} / \mathrm{kg}$ body weight. All treatment was done orally using oro-pharyngeal cannula. The hypertensive rats were also fed with commercial rat pellet but allowed access to clean drinking water with $2 \% \mathrm{NaCl}$ ad libitum.

\subsection{Sample Collection and Analysis}

The rats were dosed for five (5) weeks and they were humanely sacrificed at the end of the $5^{\text {th }}$ week. The male genitalia were surgically exposed to harvest the cauda epididymis and the left testicle. Semen samples from the cauda epididymis were analyzed for motility, sperm concentration, Live-Dead ratio and count. The cauda epididymis was incised and a sample of the semen was put on glass slide and a drop of normal saline was added. The glass slide was covered with cover slip and viewed under microscope to check for the motility.

Smear of the same glass slide used for motility test was used for Live-dead ratio and Morphology. The glass slide was stained with Eosin-Nigrosine and viewed under Light microscope. Spermatozoa morphology determined include headless tail, tailless head, rudimentary tail, curved tail, bent tail, curved midpiece, bent mid-piece and looped tail. The cauda epididymis was crushed in $5 \mathrm{ml}$ Normal Saline. A drop of the cauda epididymis homogenate was placed on haemocytometer and viewed under light microscope for Sperm concentration.

\subsection{Statistical Analysis}

Data from this study were presented as mean \pm Standard Error of Mean (SEM). Differences between the mean values were determined at $p<0.05$ using one-way ANOVA and Duncan post-hoc test on GraphPad Prism 5.0.

\section{RESULTS}

\subsection{Sperm Morphology}

There was a non-significant increase in the number of spermatozoa with normal head without tail in all the groups. The percentage abnormality in rats group 5 was highest $(5.0 \pm 0.55 \%)$. A non-significant increase was observed in the number of spermatozoa with normal tail without head but the rats in Group 3 had a lesser number $(4.0 \pm 0.55 \%)$ when 
compared to others. There was a non significant increase in spermatozoa with rudimentary tail, though the increase was observed in group 2 $(1.6 \pm 0.40 \%)$, group $5(1.8 \pm 0.37 \%)$, group 6 $(2.0 \pm 0.45 \%)$, group $7(2.0 \pm 0.45 \%)$ and group 8 $(2.0 \pm 0.45 \%)$ compare to those in group 1 (control group) 0 r 3 or 4 with same number of abnormality $(1.4 \pm 0.24 \%)$. A non-significant increase was observed in the number of spermatozoa with normal head with bend tail compared to the control group with lesser number $(8.0 \pm 0.55 \%)$ (Table 1$)$. There was a nonsignificant increase in the number of spermatozoa with normal head with curved tail compared to the control group with lesser number $(8.0 \pm 0.55 \%)$ of abnormality. The rats in the control group had lesser number of spermatozoa with curved mid-piece abnormality $(8.0 \pm 0.32 \%)$ but was slightly higher in hypertensive group $2(8.8 \pm 0.37 \%)$, in treatment group 3 and $4(10.8 \pm 0.37 \%)$ with same number or $5(10.4 \pm 0.87 \%)$ and $7(10.6 \pm 0.68 \%)$ when compared with treatment group $6(11.6 \pm 0.81 \%)$ and $8(11.4 \pm 0.68 \%)$ with highest abnormality (Table 1).

The occurrence of bent mid-piece spermatozoa was slightly lesser in the control group $(9.0 \pm 0.45 \%)$ compared to others, while the highest percentage abnormality was observed in group $8(11.2 \pm 0.20)$. A non-significant increase in the occurrence of looped tail spermatozoa was observed. Rats in group 2 had same population of looped tail spermatozoa with the control group $(1.6 \pm 0.40)$. Treatment rats in group $4(2.6 \pm 0.50)$ had the highest population of sperm abnormality with looped tail. A significant reduction was observed in the total sperm count of all the Hypertensive rats when compared with the control group (412 $\pm 1.22 \%)$. Rats in group 6, 7 and 8 had same number of total sperm count $(406 \pm 2.92 \%)$ while rats of group 5 had the least number of total sperm count $(403 \pm 2.00 \%)$. There was a significant increase in percentage sperm abnormality of all treatment rats. Rats of group 2 $(10.02 \%)$ has a lesser percentage sperm abnormality when compared with the control group (10.83\%) (Table 1).

\subsection{Sperm Characteristics}

A significant reduction in sperm motility was observed. The sperm motility in the rats of the control group is significantly higher $(93.2 \pm 0.92 \%)$ compared to rats in each of the treatment group. There was non-significant reduction in the live: dead ratio for each rats in the treatment group, compared to the control group. A non-significant increase was observed in the volume of spermatozoa for each of the treatment groups compared to the control group. Rats in group 4 had same volume with the rats of the control group (5.14 $\pm 0.02 \%)$, while rats of group 2, 5, 6, 7 and 8 had same volume $(5.18 \pm 0.02)$ compared to rats of group 3 with least increase $(5.16 \pm 0.02)$ compared to control group. Apparently, its statistically unchanged. A significant reduction in sperm count in rats of the treatment groups was observed compared to the rats of the control group with the highest sperm count (142.8 \pm 4.10$)$. Rats of group 8 had the least sperm count $(93.0 \pm 4.76)$ when compared to rats in the other group (Table 2).

\section{DISCUSSION}

This study evaluated the toxicological effect of methanol extract administration of $L$. breviflora Roberty and Xanthosoma sagittifolium Schott on male reproductive system of Wistar rats using total sperm cell count, morphology, motility and live/dead sperm cell ratio. Male fertility can be assessed by these andrological parameters as indices of ability of a sperm cell to fertilize a fertile ovum, with $>50 \%$ abnormal sperm cells, $<50 \%$ motility and $<20 \times 10^{6} / \mathrm{ml}$ cells considered critical percentages in human males [21,22].

The sperm cell morphological abnormalities are classified as primary or secondary abnormalities and both types were observed in rats orally administration of $L$. breviflora Roberty and $X$. sagittifolium Schott in this study [23]. The only primary sperm abnormality was rudimentary tail, while normal head without tail, normal tail without head, bent tail, curved tail, curved mid-piece, bent mid-piece, and looped were secondary abnormalities observed. Primary abnormalities are usually associated with the spermatogenesis, while secondary abnormalities are usually due to changes taking place during maturation and storage of spermatozoa in the epididymis [18].

A non-significant increase in rudimentary tail sperm abnormality was observed in rats treated with the extracts relative to the control rats, while those treated with Lisinopril and hydrochlorothiazide had similar total number of abnormal sperm cells. Aberrations in the process of spermatogenesis cause primary sperm abnormality with rudimentary tailed cells usually immotile, and unable to fertilize mature ovum [24]. 
Table 1. Percentage occurrence of different sperm abnormalities observed in the rats of the control and test groups

\begin{tabular}{|c|c|c|c|c|c|c|c|c|c|c|}
\hline Group & $\begin{array}{l}\text { Tail-less } \\
\text { head }\end{array}$ & $\begin{array}{l}\text { Headless } \\
\text { tail }\end{array}$ & $\begin{array}{l}\text { Rudimen- } \\
\text { tary tail }\end{array}$ & Bent tail & $\begin{array}{l}\text { Curved } \\
\text { tail }\end{array}$ & $\begin{array}{l}\text { Curved } \\
\text { mid-piece }\end{array}$ & $\begin{array}{l}\text { Bent mid- } \\
\text { piece }\end{array}$ & $\begin{array}{l}\text { Looped } \\
\text { tail }\end{array}$ & $\begin{array}{l}\text { Total sperm } \\
\text { count }\end{array}$ & $\begin{array}{l}\text { \%Sperm } \\
\text { Abnormality }\end{array}$ \\
\hline Ctrl & $4.2 \pm 0.37$ & $4.4 \pm 0.51$ & $1.4 \pm 0.24$ & $8.0 \pm 0.55$ & $8.0 \pm 0.55$ & $8.0 \pm 0.32$ & $9.0 \pm 0.45$ & $1.6 \pm 0.40$ & $412 \pm 1.22$ & 10.83 \\
\hline Hypert & $4.2 \pm 0.58$ & $4.4 \pm 0.51$ & $1.6 \pm 0.40$ & $9.2 \pm 0.20$ & $9.4 \pm 0.24$ & $8.8 \pm 0.37$ & $9.6 \pm 0.40$ & $1.6 \pm 0.40$ & $406 \pm 2.91$ & 12.02 \\
\hline Lisinop & $4.2 \pm 0.58$ & $4.0 \pm 0.55$ & $1.4 \pm 0.24$ & $10.0 \pm 0.32$ & $10.4 \pm 0.92$ & $10.8 \pm 0.37$ & $10.2 \pm 0.20$ & $1.8 \pm 0.37$ & $405 \pm 2.77$ & 13.02 \\
\hline Hydrochl & $4.4 \pm 0.51$ & $4.4 \pm 0.51$ & $1.4 \pm 0.24$ & $10.4 \pm 0.24$ & $10.0 \pm 0.84$ & $10.8 \pm 0.37$ & $10.2 \pm 0.20$ & $2.6 \pm 0.50$ & $407 \pm 2.55$ & 13.32 \\
\hline Lb100 & $5.0 \pm 0.55$ & $4.6 \pm 0.51$ & $1.8 \pm 0.37$ & $10.0 \pm 0.45$ & $10.6 \pm 0.87$ & $10.4 \pm 0.60$ & $10.4 \pm 0.93$ & $2.2 \pm 0.37$ & $403 \pm 2.00$ & 13.77 \\
\hline Lb200 & $4.6 \pm 0.51$ & $4.4 \pm 0.51$ & $2.0 \pm 0.45$ & $9.8 \pm 0.86$ & $11.2 \pm 1.07$ & $11.6 \pm 0.81$ & $10.4 \pm 0.87$ & $2.2 \pm 0.37$ & $406 \pm 2.92$ & 13.84 \\
\hline Xs100 & $4.6 \pm 0.51$ & $4.6 \pm 0.60$ & $2.0 \pm 0.45$ & $10.2 \pm 0.37$ & $10.6 \pm 0.68$ & $10.6 \pm 0.68$ & $10.2 \pm 0.37$ & $2.0 \pm 0.45$ & $406 \pm 2.92$ & 13.50 \\
\hline Xs200 & $4.6 \pm 0.51$ & $4.8 \pm 0.37$ & $2.0 \pm 0.32$ & $10.0 \pm 0.45$ & $11.0 \pm 0.55$ & $11.4 \pm 0.68$ & $11.2 \pm 0.20$ & $2.2 \pm 0.37$ & $406 \pm 2.92$ & 14.10 \\
\hline
\end{tabular}

Hypert - Hypertensive not treated, Lisinop - Lisinopril $5 \mathrm{mg} / 70 \mathrm{~kg}$, Hydrochl - Hydrochlorothiazide $12.5 \mathrm{mg} / 70 \mathrm{~kg}$, Lb100/Lb200 - Lagenaria breviflora extract $100 \mathrm{mg} / \mathrm{kg}$ or $200 \mathrm{mg} / \mathrm{kg}$, Xs100/Xs200 - Xanthosoma sagittifolium extract $100 \mathrm{mg} / \mathrm{kg}$ or $200 \mathrm{mg} / \mathrm{kg}$

Table 2. Sperm motility, liveability and count, and seminal volume of hypertensive Wistar rats treated with L. breviflora Roberty fruit or $X$. sagittifolium Schott corm

\begin{tabular}{llll}
\hline Group & Motility (\%) & Live/Dead (\%) & Volume (cm3) \\
\hline Control & $93.2 \pm 0.92$ & $97.2 \pm 0.58$ & $5.14 \pm 0.02$ \\
Hypertensive & $78.0 \pm 2.00^{*}$ & $96.2 \pm 0.73$ & $5.18 \pm 0.02$ \\
Lisinopril & $74.0 \pm 2.45^{*}$ & $96.8 \pm 0.73$ & $5.16 \pm 0.02$ \\
Hydrochloro & $76.0 \pm 2.45^{*}$ & $96.8 \pm 0.73$ & $5.14 \pm 0.02$ \\
Lb100 & $74.0 \pm 2.45^{*}$ & $96.2 \pm 0.73$ & $5.18 \pm 0.02$ \\
Lb200 & $78.0 \pm 3.74^{*}$ & $96.8 \pm 0.73$ & $5.18 \pm 0.02$ \\
Xs100 & $76.0 \pm 2.45^{*}$ & $96.8 \pm 0.73$ & $5.18 \pm 0.02$ \\
Xs200 & $74.0 \pm 2.45^{*}$ & $96.8 \pm 0.73$ & $5.18 \pm 0.02$ \\
\hline
\end{tabular}

Hypertensive - Hypertensive not treated, Lisinopril - Lisinopril 5 mg/70 kg, Hydrochloro - Hydrochlorothiazide $12.5 \mathrm{mg} / 70 \mathrm{~kg}, \mathrm{Lb100} / \mathrm{Lb200}$ - Lagenaria breviflora extract 100 $\mathrm{mg} / \mathrm{kg}$ or $200 \mathrm{mg} / \mathrm{kg}$, Xs100/Xs200 - Xanthosoma sagittifolium extract $100 \mathrm{mg} / \mathrm{kg}$ or $200 \mathrm{mg} / \mathrm{kg}$ 
Secondary abnormality recorded a nonsignificantly $(p>0.05)$ higher incidence of bent mid-piece and tail, closely followed by curved mid-piece and tail. The other secondary sperm abnormalities observed were tailless head, headless tail and looped tail. These abnormalities occur in the process of maturation of sperm cells in the seminiferous tubules [25]. The total abnormal cells were non-significantly increased with a decrease in total sperm count. It can be inferred from this study that prolonged administration of the fruit extract of $L$. breviflora Roberty and corm of $X$. sagittifolium Schott may have deleterious effects on the both spermatogenesis and maturation. Treatment of hypertension is usually life-long in established clinical cases.

Sperm morphology as well as characteristics were adversely affected by prolonged administration of the extract, as sperm motility and count in rats in the treatment groups were significantly reduced compared to those observed in the control group, but the live/dead sperm cells ratio and volume were within the same range as those of the control rats. A previous study on methanol extract of $L$. breviflora in normal Wistar rats administered with the extract for 14 days showed a similar result [18]. Comparing these two studies may give some insight into likely reproductive toxicity that may be encountered in a more prolonged administration of L. breviflora.

A contrary report was documented by Farombi et al. [26] for Curcuma longa L. (family Cucurbitaceae) showing its ability to prevent peroxidative changes in the sperm and testicular membrane, thereby enhancing sperm motility and decreasing spermatozoa abnormalities. Also, whole plants of Colocasia esculenta $L$. (family Araceae), a close relative of $X$. sagittifolium Schott is believed to induce fertility which is contrary to effect of $X$. sagittifolium Schott [27]. Aqueous extract of stem bark of Lophira lanceolata was reported to be a fertility enhancer in male Sprague dawley rats demonstrated by increased sperm numbers without alterations in sperm motility and morphology [28]. Ekere et al. [29] also reported that methanol extract of leaves of Draceana arborea had fertility enhancing activities in male Sprague dawley rats by increase sperm numbers and increase the mean testicular weight.

\section{CONCLUSION}

Findings in this study show that hypertension itself induced infertility in male Wistar rats due to reduced blood flow to the seminiferous tubules in hypertensive patient which induce degeneration of the seminiferous tubules causing significant reduction in total sperm count. The oral administration of the extracts of the fruit of $L$. breviflora Roberty and corm of $X$. sagittifolium Schott respectively causes increased sperm cell abnormalities with more secondary abnormalities than the primary sperm cells abnormalities. This suggests that prolonged administration of these extract may cause a marginal and nonsignificant further progression of the infertility caused by hypertension. Therefore, care should be taken in the use of this medicinal plant for treatment of hypertension in both human and animals especially male animals used for breeding.

\section{ETHICAL APPROVAL}

All authors hereby declare that "Principles of laboratory animal care" (NIH publication No. 8523 , revised 1985) were followed, as well as the code of conduct of Animal Experimentation set by Animal Care and Use Research Ethics Committee (ACUREC), University of Ibadan, Nigeria. All experiments have been examined and approved by the ethics committee.

\section{COMPETING INTERESTS}

Authors have declared that no competing interests exist.

\section{REFERENCES}

1. Gadea J. Sperm factors related to in vitro and in vivo porcine fertility. Theriogenol. 2005;63(2):431-444.

2. Toppari J, Larsen JC, Christiansen P, Giwercman A, Grandjean P, Guillette LJ, Jégou $B$, Jensen TK, Jouannet $P$, Keiding $N$, Leffers $H$, McLachlan JA, Meyer $O$, Müller J, Rajpert-De Meyts E, Scheike T, Sharpe R, Sumpter J, Skakkebaek NE. Male reproductive health and environmental xenoestrogens. Environ Health Perspect. 1996;104(Suppl 4):741803.

3. Phillips GB, Jing TY, Resnick LM, Barbagallo M, Laragh JH, Sealey JE. Sex hormones and hemostatic risk factors for 
coronary heart disease in men with hypertension. J Hyperten. 1993;11(7):699702

4. Fogari R, Preti P, Derosa G, Marasi G, Zoppi A, Rinaldi A, Mugellini A. Effect of antihypertensive treatment with valsartan or atenolol on sexual activity and plasma testosterone in hypertensive men. Eur J Clin Pharmacol. 2002a;58(3):177-180.

5. Fogari R, Zoppi A, Preti P, Rinaldi A, Marasi G, Vanasia A, Mugellini A. Sexual activity and plasma testosterone levels in hypertensive males. Am J Hypertens. 2002b;15(3):217-221.

6. Svartberg J, von Muhlen D, Schirmer $H$, Barrett-Connor E, Sundfjord J, Jorde R. Association of endogenous testosterone with blood pressure and left ventricular mass in men. The Tromso Study. Eur J Endocrinol. 2004;150(1):65-71.

7. Zillich AJ, Garg J, Basu S, Bakris GL, Carte BL. Thiazide diretics, potassium and the development of diabetes: A quantitative review. Hyperten. 2006;48(2): 219-224.

8. James PA, Oparil S, Carter BL, Cushman WC, Dennison-Himmelfarb C, Handler J, Lackland DT, LeFevre ML, MacKenzie TD, Ogedegbe O, Smith SC, Svetkey LP, Taler SJ, Townsend RR, Wright JT, Narva AS, Ortiz E. 2014 Evidence-Based Guideline for the Management of High Blood Pressure in Adults. JAMA. 2013;311(5): 507-20.

9. Goyal D, MacFadyen RJ. Perception of symptoms in hypertensive patients and the relevance to the application of antihypertensive drug therapy. Curr. Pharm. Des. 2006;12:1557-1565.

10. Williams $\mathrm{GH}$, Croog $\mathrm{SH}$, Levine $\mathrm{S}$, Testa MA, Sudilovsky A. Impact of antihypertensive therapy on quality of life: Effect of hydrochlorothiazide. J Hyperten. 1987;5(1): S29-35.

11. Yeh CT, Huang WH and Yen GC. Antihypertensive effects of Hsian-tsao and its active compound in spontaneously hypertensive rats. J. Nutr. Biochem. 2008; 20:866-875.

12. Maghrani $M$, Zeggwagh NA, Haloui $M$, Eddouks M. Acute diuretic effect of aqueous extract of Retama raetam in normal rats. J. Ethnopharmacol. 2005;99: 31-33.

13. Vasant OK, Vijay BG, Virbhadrappa SR, Dilip NT, Ramahari MV, Laxamanrao BS. Antihypertensive and diuretic effects of the aqueous extract of Colocasia esculenta Linn. Leaves in Experimental Paradigms. Iran J Pharm Res. 2012;11(2):621-634.

14. Azza OFE, Afaf IA, Galal M. Toxicopathological effects of Guiera senegalensis extracts in wistar albino rats. J Med Plants Res. 2009;3(10):699-702.

15. Sonaiya EB. Family Poultry and Food Security. Research requirement in Science, Technology, and Socioeconomics; 1999.

Available:http:///www.fao.org/WAICENT/fa o/INFO/AGRICULT/AGAInfo/subjects/en/in fpd/documents/papers/2000/4SONAIYA.D OC

16. Onasanwo $S A$, Singh $N$, Saba $A B$, Oyagbemi AA, Oridupa OA, Palit G. Antiulcerogenic and in vitro antioxidant activities of Lagenaria breviflora (LB) whole fruit ethanolic extract in laboratory animals. Pharmacognosy. Res. 2011;3:2-8.

17. Oridupa OA, Saba AB. Relative antiinflammatory and analgesic activities of the whole fruit, fruit bark, pulp and seed of Lagenaria breviflora Roberty. J Pharmacol Toxicol. 2012;7(6):288 -297.

18. Saba AB, Oridupa OA, Oyeyemi MO, Osanyingbe OD. Spermatozoa morphology and characteristics of male Wistar rats administered with ethanolic extract of Lagenaria breviflora Roberts. Afr J Biotech. 2009;8(7):1170-1175.

19. Folasire OF, Oridupa OA, Owolabi AJ, Adepoju OT. Anti-hyperglycemic effect of cocoyam (Xanthosoma sagittifollium) corm in alloxan-induced diabetic albino rats. Int J Nutri Metab. 2016;8(4):24-29.

20. de Almeida JE, Monteiro EB, Raposo HF, Vanzela EC, Amaya-Farfán J. Taioba (Xanthosoma sagittifolium) leaves: Nutrient composition and physiological effects on healthy rats. J Food Sci. 2013;78(12): H1929-34.

21. Rogers BJ, Bentwood BJ, Van Campen $\mathrm{H}$, Helmbrecht G, Soderdahl D, Hale RW. Sperm morphology assessment as an indicator of human fertilizing capacity. J Androl. 1983;492:119-125.

22. Garner DL, Hafez ESE. Spermatozoa and seminal plasma. In Hafez ESE (Eds.) Reproduction in Farm animals ( $6^{\text {th }} \mathrm{Ed}$.) Lea and Febiger, Philadelphia, USA. 1993; 165-187.

23. Noarkes DE, Parkinson TJ, England GCW, Arthur GH. Normal reproduction in male animals. In: Arthur's Veterinary Reproduction and Obstetrics. $8^{\text {th }}$ Edn. 
Saunders Publishers, Edinburgh. 2004; 673-694.

24. Beletti ME, Mello MLS. Comparison between the toluidine blue stain and the Feulgen reaction for evaluation of rabbit sperm chromatin condensation and their relationship with sperm morphology. Theriogenol. 2004;62(3-4):398-402.

25. Thomas MJ, Thomas JA. Toxic responses of the reproductive system. In: Casarett \& Doull's Toxicology- The basic science of poisons $\left(6^{\text {th }} \mathrm{Ed}\right)$, McGraw-Hill Medical Publishing Division, New York. 2001;677681.

26. Farombi EO, Abarikwu SO, Adedara IA, Oyeyemi MO. Curcumin and kolaviron ameliorate di-n-Butylphthalate-induced testicular damage in rats. Basic Clin Pharmacol Toxicol. 2007;100:43-48.

27. Deka J, Kalita JC. Enthobotanically important medicinal plants of Kamrup District, Assam, India used in Infertility Treatment. Int Res J Pharm. 2013;4(3): 229-232.

28. Etuk EU, Muhammad AA, 2009. Fertility enhancing effects of aqueous stem bark extract of Lophira lanceolata in male Spargue dawley rats. International J Plant Physiol Biochem. 2009;1(1):1-4.

29. Ekere SO, Okoye CN, Udoumoh AF. Fertility enhancing effects of methanolic leaf extract of Dracaena arborea in albino rats (Rattus norvegicus). Czech J Anim Sci. 2013;58(11):520-524.

(c) 2018 Oridupa et al.; This is an Open Access article distributed under the terms of the Creative Commons Attribution License (http://creativecommons.org/licenses/by/4.0), which permits unrestricted use, distribution, and reproduction in any medium, provided the original work is properly cited.

Peer-review history:

The peer review history for this paper can be accessed here: http://www.sdiarticle3.com/review-history/47027 